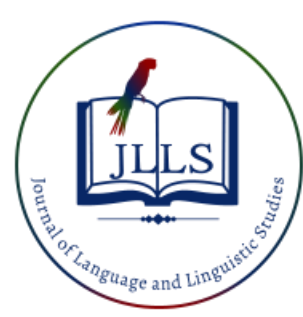

Available online at www.jlls.org

JOURNAL OF LANGUAGE AND LINGUISTIC STUDIES

ISSN: $1305-578 \mathrm{X}$

Journal of Language and Linguistic Studies, 16(3), 1167-1176; 2020

\title{
Teachers' perceptions of the role of parental involvement in teaching English to
} young learners

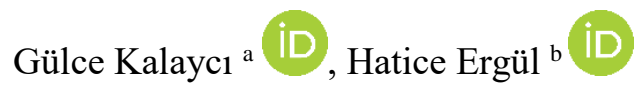 \\ ${ }^{a}$ Ufuk University, Ankara, Turkey \\ ${ }^{b}$ Hacettepe University, Ankara, Turkey
}

\section{APA Citation:}

Kalayc1, G., \& Ergül, E. (2020). Teachers' perceptions of the role of parental involvement in teaching English to young learners. Journal of Language and Linguistic Studies, 16(3), 1167-1176.

Submission Date: 18/02/2020

Acceptance Date: 01/07/2020

\begin{abstract}
The role that parents' involvement play in young learners' English learning process has been investigated in various contexts from different perspectives. This study aims to explore English language teachers' perceptions about the role of parental involvement in young learners' English language learning process. For this purpose, data were collected through a questionnaire which has 5 open-ended questions. The questionnaire was sent to 25 English language teachers working at three different private primary schools in Ankara. The collected data are then analyzed by adopting inductive content analysis. Five themes emerged based on the answers provided by the teachers which include: (1) factors influencing students' achievement, (2) significance of parental involvement, (3) parents' way of involvement in English language teaching/learning process, (4) strategies that parents use to encourage parental involvement, and (5) teachers' need for further training on parental involvement. The results indicate that the teachers are aware of the importance of parental involvement, yet they do not use any specific strategy to foster parental involvement. Also, teachers view themselves as the lead and main figures in young learners' English language development whereas they regard the parents only as one of the factors that assist young learners in learning English.
\end{abstract}

C 2020 JLLS and the Authors - Published by JLLS.

Keywords: parental involvement; teachers' perception; teaching English to young learners; English language teachers; content analysis

\section{Introduction}

Parents can be seen as the first teachers of their children, and some parents are not willing to abandon this role even when their children start school. Parents are usually active participants of children's formal education, which promotes children's social, emotional and academic development (Green, Walker, Hoover-Dampsey \& Sandler, 2007). Parental involvement can be defined as the actions that parents perform in order to enhance their children's school achievement in cooperation with teachers and other school staff (Mcneal Jr, 2014). Regarding the extent of the present study, research conducted in the field of English language teaching suggests that parental involvement promotes second language (L2) development of students in various aspects including social, emotional, and academic (Niehaus \& Adelson, 2014). Anderson (2000) proposes that parents' active involvement in children's education 
improves their academic achievement and also cognitive growth. Barón and Corredor (2007) also indicate that communication and collaboration between parents and teachers pave the way for accomplishment of the educational objectives (As cited in Castillo \& Camelo, 2013). Since parental involvement can only be achieved through teachers' and parents' joint efforts, it is essential to understand their viewpoints about it. This study will exclusively focus on the parents' involvement in the process of teaching English to young learners from the teachers' perspective.

\subsection{Literature review}

There is a growing body of research on the role of parental involvement in children's academic achievement including their L2 development (see Al-Mahrooqi, Denman \& Maamari, 2016; Kotaman, 2008; Niehaus \& Adelson, 2014; Panferov, 2010). However, there is still a lack of consensus on a precise definition of what parental involvement is. In fact, it seems to be interpreted differently based on the focus of research. Some researchers define parental involvement as the parents' dedication of a good deal of resources to the children's education (Grolnick \& Slowiaczek, 1994). Another available definition of parental involvement refers to the parental activities performed at home or school regarding to the children's education (Hoover-Dampsey \& Sandler, 1997). Ryan, Cadas, Kelly-Vance, Ryallas and Nora (2010) highlight that parental involvement reflects parents' communication with the school staff regarding the students' education in addition to their involvement in academic events. As such, it is acknowledged that parental involvement is a complex concept which is mainly built upon the interaction between parents and teachers (Morgan, Fraser, Dunn \& Cairns, 1992).

Christianakis (2011) explains parental involvement referring to two different models involving (1) parent empowerment model, and (2) parent-teacher partnership model. The first model deals with the opportunities that can promote parents' engagement in children's education while the second one represents partnership between parents and teachers. Her research proposes that teachers view parents as "help labors" (Christianakis, 2011) rather than "equal partners", which shows consistency with parents' point of view regarding parental involvement in Turkish context. Previous research on parental involvement which have been carried out in Turkey point out that parents view parental involvement as a crucial factor which has a great impact on children's education; however, they still believe that schools have the main responsibility in children's education (Erdener \& Knoeppel, 2018; Author \& Co-Author, 2018). On the other hand, Göktürk \& Dinçkal (2017) have highlighted that teachers and parents may have different viewpoints about parental involvement as teachers, in their study, regarded parental involvement as the support given by parents to children during home activities such as homework or projects while parents desire to have a voice in educational decisions. As such, the incompatibility between parents' and teachers' perspectives decreases the efficiency of their partnership (Göktürk \& Dinçkal, 2017). On the other hand, it is argued that students become more successful when the parents and teachers work collaboratively (Hoover-Dempsey \& Sandler, 1995).

In their study on teachers' perspective on parental involvement, Pakter \& Chen (2013) suggest that teachers who are aware of the importance of parental involvement employ several strategies for improving parents' involvement in education, such as calling and e-mailing home, sending newsletters home, setting up websites for parents to follow their children's progress, etc., which highlights the significance of increasing teachers' awareness on the importance of parental involvement. Additionally, George and Mensah (2010) have revealed that parental involvement is boosted when the schools attempt to improve it in an organized and planned way. George and Mensah (2010) have also highlighted the fact that parents need to follow teachers' instructions in order to reinforce children's academic achievement, which places a great importance on teachers' practices. Calzada et al. (2015) emphasizes the importance of teachers' beliefs and practices on the effectiveness of parental involvement. In Turkish context, Hakyemez (2015) examines early childhood teachers' beliefs about parental 
involvement. She has found out that teachers give importance to parental involvement in terms of providing children support with their academic achievement at home. On the other hand, she has also reported that parental involvement was ineffective because of the parents' unwillingness to participate.

Overall, there seems to be some evidence to indicate that parental involvement has a significant influence on students' education including their L2 development. However, researchers still could not build a consensus about how parents are supposed to get involved in students' education. Little is known about how teacher conceptualize parents' involvement in teaching English to young learners. Therefore, the purpose of this investigation is to explore parental involvement from teachers' perspective in the context of teaching English to young learners.

\subsection{Research questions}

The major objective of this study is to find out English language teachers' perceptions about the role of parental involvement in young learners' English learning process. For this reason, this research aims to address the following research questions:

(1) What is the role of parental involvement in young learners' English learning process according to English teachers?

(2) Do teachers in this study believe that parents' involvement in young learners' language learning process is effective?

(3) Do teachers apply any strategy to involve parents in language teaching process?

\section{Method}

\subsection{Participants}

The participants of this study are 25 primary school English language teachers who work in three different private schools in Ankara. The sample for this study was selected randomly using cluster sampling method. Since we aim to reveal teachers' perceptions on parental involvement in teaching English to young learners, we incorporated the teachers working in 3 different primary schools into the study.

\subsection{Instrument}

In order to answer the research questions stated above, a questionnaire which includes five openended questions was created by the researchers. The questionnaire items can be listed as follows:

(1) What factors do you think affect the students' achievement?

(2) Do you think parental involvement is a significant factor affecting students' achievement? Explain.

(3) Do parents get involved in students' foreign (English) language education? How?

(4) Do you use any strategy to make parents get involved in students' foreign (English) language education process? Explain.

(5) Do you need any training for further knowledge about parental involvement? Why/Why not? 


\subsection{Data Collection Procedures}

The questionnaire was delivered to the 25 English teachers. The participants were asked to answer these questions in two days based on their past-experiences and beliefs on the issue. The participants were informed that their names and other demographic information about them would remain confidential. The participants were also asked to answer these questions sincerely by explaining the underlying reasons of their ideas.

\subsection{Data analysis}

Once the data were collected, they were first analyzed for identifying the emerging themes and areas for further examination through inductive analysis. Based on the themes emerged, the formal coding process was conducted. Throughout the process, the conceptual codes by which the phenomena are grouped in the data were identified and labelled. Five themes emerged based on the questions directed to the teachers including (1) factors influencing students' achievement, (2) significance of parental involvement, (3) parents' way of involvement in English language teaching/learning process, (4) strategies that parents use to encourage parental involvement, and (5) teachers' need for further training (Figure1). Once the coding process was completed, the codes were re-read for significance and authenticity to ensure that the themes reflected the participants' views rather than the researchers'. No counter-evidence was found.

\section{Results}

This study investigates the participants' perceptions about parental involvement in young learners' English language teaching/learning process through the answers provided by the participants to five open-ended questions. The inductive content analysis revealed five emergent themes about parental involvement in the answers provided by the English teachers who took part in the study. A summary of the emergent themes is illustrated in Table 1.

Table 1. Themes of teachers' perceptions about parental involvement in English teaching

\begin{tabular}{l}
\hline Themes \\
\hline (1) Factors influencing students' achievement \\
(2) Significance of parental involvement \\
(3) Parents' way of involvement in English language \\
(4) Strategies teachers use to encourage parental involvement \\
(5) Teachers' need for further training on parental involvement
\end{tabular}

The first theme, factors influencing students' achievement, has emerged mostly in participants' answers to the questions regarding what influences students' achievement. The second theme, significance of parental involvement, refers to how much importance the teachers give to the parents' engagement in language teaching/learning process as well as their awareness about parental involvement. The third theme, parents' way of involvement in English language teaching/learning process, describes parents' attempts for engaging in their children's language learning process from the teachers' perspectives. The fourth theme, the strategies teachers use to encourage parental involvement, 
to teachers' initiatives for engaging parents in students' language learning process. The last theme, teachers need for further training on parental involvement, refers to the teachers' possible need for training in order to increase their awareness on the role of parental involvement and also to get in contact with the parents more efficiently. These themes will be discussed in detail one by one in the following section.

\section{Discussion}

\subsection{Factors influencing students' achievement}

The analysis has revealed that the teachers who participated in this study believe that there are many factors which all have an impact on young learners' language learning process. We can group the factors that the teachers mention into two categories: (1) individual differences, and (2) environmental factors. Individual differences that are mentioned in the corpus include: gender, attitude, aptitude and motivation. Environmental factors, on the other hand, can be summarized as socio-economic status, materials, teaching methods and techniques, and teachers' motivation. The main focus of this research, factors related to the parental involvement, have been stated by almost half of the participants. The participants specially address parental involvement, parent-teacher partnership and parents' expectations. Following quotes express the teachers' opinions about the factors influencing students' achievement:

"There are several factors that affect students' achievement: gender, place of living, family, background, support of parents, socioeconomic status, etc."

"The supports of the parents and teachers. And I think the diversity of student profiles in the same class."

"School, teacher, parents, age, gender"

\subsection{Significance of parental involvement}

Previous research has shown that the teachers believe that cooperation between school and parents has a fundamental influence on students' academic achievement (Göktürk \& Dinçkal, 2017). Hakyemez (2015) provides some supporting evidence for the argument that the teachers are aware of the importance of parental involvement. Participants in Hakyemez's study indicated that parents' are the first role models of the students and the harmony in attitudes between home and school is important in order to construct an appropriate environment for the students. Likewise, Niehaus and Adelson (2014) recognized the importance of parental involvement in students' L2 development. The present study, with regard to the significance of parental involvement in young learners' language learning, has revealed three major themes that emerged in our data. These themes include: (1) parents' perceptions about English; (2) the nature of support that parents can provide at home; and (3) students' age level.

A few teachers (16\%) have mentioned that parents' perceptions about learning English has an important role in the quality of parental involvement. The following quote highlights this point:

"Parental involvement affect the students achievement. Parents approach to language learning affects the students approach automatically."

Participants in our study have also highlighted the importance of the nature of support given by the parents as they asserted that parents need to be aware of how to help their children so that parental involvement can achieve its goals. This idea can be seen in the quotations provided below. 
"At first, parents should plant the idea that knowing English is very important. Later, during this process of learning, parents should help their children with their activities, homework, etc. Children should be exposed to English as much as possible. Therefore, parents should provide their children with this environment to boost their learning process."

"When the parents know how to help their kids during their learning process, the kids learn faster and better, and for parents to know the way, teachers are the key. We, as teachers, should lead the parents."

The second statement also supports the findings of Christianakis (2011) which argued that in language learning process the teachers view themselves as "authors" who have the main responsibility' and the parents as "assistants" who are only expected to help young learners reinforce their achievement. However, Epstein et al. (2002) supports the idea that teachers and parents need to construct an effective partnership converging on a mutual goal in order to reinforce the students' achievement.

Finally, teachers mention the relation between students' age level and parents' involvement. They explained that parental involvement decreases as the age of the students increases as can be seen in the following quote:

"In my opinion, parental involvement is an important part of the learning process. Especially, when it comes to the very young and young learner groups, they mostly needed their parents' physical and motivational support in a higher level. While their ages increase, parental involvement turns into be more invisible because they should start to be independent learners."

\subsection{Parents' way of involvement in English language teaching/learning process}

Previous research have suggested that the nature of parents' involvement is heavily influenced by parents' own proficiency level in English (Moosa, Karabenick and Adam, 2001). That is the higher the parents' own proficiency level in English, the more they will be engaged in their children's language learning process. Also, their findings have suggested that low proficiency level in English has led parents to be unwilling to get involved in their children's language learning process. Our study provides some supporting evidence for this argument as can be seen in the following quotation:

"It depends on how much parents speak the language that students learn. If they could speak in the language they can come up with ideas that can contribute the students' language learning process."

The teachers have also emphasized that parental involvement covers not only homework involvement but also parents' social and emotional assistance regarding students' L2 development, which shows that the teachers are aware of the multifaceted influence of parental involvement on students' educational development as the previous research suggests (Emerson, Fear, Fox, \& Senders, 2012). Moreover, the teachers explained that parents' characteristics determine their level and kind of involvement in students' language learning process, which is illustrated with the following quote:

"Parents take a place in their children's education process on purpose or unconsciously. Their behaviors, reactions, educational and cultural backgrounds are all concrete milestones of students foreign language education. If the parents of the learners are volunteer to be part of the foreign languages world, the target student could be more interested in these cases, too."

\subsection{Strategies teachers use}

Each teacher states that s/he uses different strategies in order to make the parents get involved in language learning process such as using applications in order to share classroom experiences with the parents, sending weekly messages reporting the school activities and outputs, informing parents about students' behavioral problems, giving students homework necessitating parent support etc. The teachers' 
examples imply that they prefer sharing information with the parents rather than asking their suggestions, which the following quotes clearly show:

"We involve parents by sending some video homework and detailed parental letters."

"Every Friday we send an information message about the topics that we follow in the week through K12 to the parents. I want the parents to repeat the vocabulary with their children at the weekends."

In addition, teachers state that they make the parents engaged in the language learning process through various activities directing to them. However, the teachers predominantly restrict parental involvement as homework involvement, which is consistent with the previous research (Hakyemez, 2015). None of the participants mentions any strategy for involving parents in school activities. The following quotes exemplify the strategies that teachers deploy for engaging parents in L2 learning process

"As the department, we assign the students with an English word notebook and they often ask help from their parents. They at least help their children find the words from the dictionary."

"I advise the parents to buy efficient materials. I make lists of movies, videos or applications they can use to assist their children's L2 development."

"For every unit, I share the new words with their concrete pictures and pronunciation so that they can study together. Every week, I share a phrase with them to use every day."

This theme is significant because of the fact that previous research shows that the strategies used by the schools and teachers are the predictors of parental involvement (Göktürk \& Dinçkal, 2017; Niehaus \& Adelson, 2014); therefore, the teachers need to give importance to the strategies that they use for engaging the parents in learning process effectively.

\subsection{Teachers' need for further training on parental involvement}

$72 \%$ of the teachers state that they need further training about parental involvement techniques. They are in the opinion that everybody, especially teachers, need training for life-long learning. Besides, they express that teachers need to improve themselves in order to reinforce the students L2 learning process in different aspects. The following quote summarize the teachers' general understanding:

"Actually, being a teacher is in every ending process which implies continual improvement through learning and training. A teacher should be like a rolling stone going through different fields and knowledge. I would encourage teachers to have more involvement in understanding psychology and sociology of learning. These are the dynamics that shape teaching and learning today."

On the other hand, $28 \%$ of the teachers claim that they do not need any training on parental involvement. Some of them believe that they do everything they can do in order to teach English to the students. This point of view contradicts with Hakyemez' (2015) findings showing that teachers feel insufficient about the strategies used for involving parents in learning process. One of the teachers claim that the parents need for training because they do not engage in the process however hard she tries:

"It is hard to involve parents in learning process. Sometimes, they even do not read the messages I send for informing about students' homework. This kind of training should be better for the parents rather than me."

Previous research (Castillo \& Gamez, 2013) verifies this point of view. The results of the study show that training the parents about involvement strategies results in positive change in home environment and students' achievement. It implies that students' language learning process concerns not only the teachers but also the parents. Consequently, both of them needs training for better partnership. 


\section{Conclusion}

The main goal of the current study was to understand teacher's perceptions about parental involvement in teaching English to young learners. Initially, the results show that the teachers are aware of the parents' influence on the students' language development. Most of them accept the significance of parental involvement; furthermore, they claim that parents' way of involvement in teaching/learning English affects the process as much as their involvement level. To illustrate, they indicate that parents need to reinforce students' language development not only academically but also motivationally. Secondly, they believe that school and parents need to establish an efficient partnership to foster students' language development aiming at matching outcomes. However, their statements imply that they only inform the parents about the classroom activities rather than constructing a partnership. The teachers view themselves as the lead and main figures in young learners' English language development whereas they regard the parents only as assistance. Most of the teachers accept their need for further training in order to improve themselves as teachers. On the other hand, none of them specifies any particular insufficiency about parental involvement. All in all, the teachers recognize the significance of parental involvement; however, their statements show that they do not make any particular effort to foster parent-teacher partnership.

This study extends our knowledge of teachers' perception about parental involvement; however, it has several limitations. To begin with, small sample size of the study does not allow to generalize the results. Secondly, the results may vary in different contexts since the data were collected from the private school teachers. Therefore, this study should be repeated in different contexts in order to improve the generalizability of the results. Thirdly, it focuses on teachers' perceptions without measuring the academic, social or psychological outcomes of parental involvement for children's English development. Consequently, the teachers may be mistaken about the effects of parental involvement in teaching English to young learners. Further research involving different outcomes of the parental involvement may give more fruitful results for parents, teachers and teacher trainers. Also, it would be interesting to compare teachers', parents' and students' perceptions regarding the role of parental involvement in teaching English to young learners in order to gain more comprehensive understanding on it.

\section{Ethics Committee Approval}

The author(s) confirm(s) that the study does not need ethics committee approval according to the research integrity rules in their country (Date of Confirmation: August 30, 2020).

\section{References}

Akkok, F. (1999). Parental Involvement in the Educational System: To Empower Parents To Become More Knowledgeable and Effective. Paper presented at the Central Asia Regional Literacy Forum, Istanbul

Al-Mahrooqi, R., Denman, C., \& Al-Maamari, F. (2016). Omani Parents' Involvement in Their Children's English Education. SAGE Open, 6(1), 1-12.

Author \& Co-Author, 2018

Calzada, E. J., Huang, K. Y., Hernandez, M., Soriano, E., Acra, C. F., Dawson-McClure, S., \& Brotman, L. (2015). Family and teacher characteristics as predictors of parent involvement in education during 
early childhood among Afro-Caribbean and Latino immigrant families. Urban education, 50(7), 870-896.

Castillo, R., \& Camelo, L. C. (2013). Assisting your child's learning in L2 is like teaching them to ride a bike: A study on parental involvement. GIST Education and learning research journal, 7, 54-73.

Christianakis, M. (2011). Parents as "help labor": Inner-city teachers' narratives of parent involvement. Teacher Education Quarterly, 38(4), 157-178.

Emerson, L., Fear, J., Fox, S., \& Sanders, E. (2012). Parental engagement in learning and schooling: Lessons from research. A report by the Australian Research Alliance for Children and Youth (ARACY) for the Family-School and Community Partnerships Bureau: Canberra.

Epstein, J. L., Sanders, M. G., Simon, B. S., Salinas, K. C., Jansorn, N. R., \& Van Voorhis, F. L. (2002). School, family, and community partnerships: Your handbook for action (2nd ed.). Thousand Oaks, CA: Corwin Press.

Erdener, M. A., \& Knoeppel, R. C. (2018). Parents' perceptions of their involvement in schooling. International Journal of Research in Education and Science, 4(1), 1-13.

George, D., \& Mensah, D. (2010). Parental involvement in homework for children's academic success: A study in the Cape Coast Municipality. Academic Leadership Journal, 8(2), 34-48.

Gokturk, S., \& Dinckal, S. (2017). Effective parental involvement in education: experiences and perceptions of Turkish teachers from private schools. Teachers and Teaching, 24(2), 183-201.

Green, C. L., Walker, J. M. T., Hoover-Dempsey, K. V., \& Sandler, H. M. (2007). Parents' motivation for involvement in children's education: An empirical test of a theoretical model of parental involvement. Journal of Educational Psychology, 99, 532-544.

Grolnick, W. S., \& Slowiaczek, M. L. (1994). Parents' involvement in children's schooling: A multidimensional conceptualization and motivational model. Child Development, 65, 237-252. http://dx.doi.org/10.1111/1467-8624.ep9406130692.

Hakyemez, S. (2015). Turkish early childhood educators on parental involvement. European Educational Research Journal, 14(1), 100-112.

Hoover-Dempsey, K. V., \& Sandler, H. M. (1995). Parental involvement in children's education: Why does it make a difference?. Teachers college record, 97(2), 310-331.

Hoover-Dempsey, K. V., \& Sandler, H. M. (1997). Why do parents become involved in their children's education? Review of Educational Research, 67, 3-42.

Kotaman, H. (2008). Türk ana babalarının çocuklarının eğitim öğretimlerine katılım düzeyleri. Uludă̆ Üniversitesi Ĕgitim Fakültesi Dergisi, 21(1).

LaRocque, M., Kleiman, I., \& Darling, S. M. (2011). Parental involvement: The missing link in school achievement. Preventing School Failure, 55(3), 115-122.

McNeal Jr, R. B. (2014). Parent involvement, academic achievement and the role of student attitudes and behaviors as mediators. Universal Journal of Educational Research, 2(8), 564-576.

Moosa, S., Karabenick, S. A., \& Adams, L. (2001). Teacher perceptions of Arab parent involvement in elementary schools. School Community Journal, 11(2), 7-26.

Morgan, V., Fraser, G., Dunn, S., \& Cairns, E. (1992). Parental Involvement in Education: how do parents want to become involved?. Educational studies, 18(1), 11-20. 
Niehaus, K., \& Adelson, J. L. (2014). School support, parental involvement, and academic and socialemotional outcomes for English language learners. American Educational Research Journal, 51(4), 810-844.

Pakter, A., \& Chen, L. L. (2013). The daily text: Increasing parental involvement in education with mobile text messaging. Journal of Educational Technology Systems, 41(4), 353-367.

Panferov, S. (2010). Increasing ELL parental involvement in our schools: Learning from the parents. Theory into Practice, 49(2), 106-112.

Ryan, C. S., Casas, J. F., Kelly-Vance, L., Ryalls, B. O., \& Nero, C. (2010). Parental involvement and views of school success: The role of parents' Latino and White American cultural orientations. Psychology in the Schools, 47, 391-405.

\section{Çocuklara İngilizce öğretiminde veli katılımının rolüne ilişkin öğretmen görüşleri}

\section{$\ddot{\mathbf{O} z}$}

Velilerin çocukların İngilizce öğrenme süreçlerine katılımları farklı bakış açılarıyla birçok araştırmaya konu olmuştur. Bu araştırma çocukların İngilizce öğrenme süreçlerinde veli katılımının rolünü İngilizce öğretmenlerinin bakış açılarıyla incelemeyi amaçlamaktadır. Bu amaç doğrultusunda, gerekli veri beş açık uçlu sorudan oluşan bir anket ile toplanmıştır. İlgili anket Ankara'da üç farklı özel okulda çalışan 25 öğretmene gönderilmiştir. Toplanan veri tümevarımsal içerik analizi (inductive content analysis) yöntemi ile analiz edilmiştir. Öğretmenlerden gelen cevaplar sonucunda beş tema ortaya çıkmıştır: (1) öğrenci başarılarını etkileyen faktörler, (2) veli katılımının önemi, (3) velilerin İngilizce öğretme/ögrrenme süreçlerine katılım yollarl, (4) öğretmenlerin veli katılımını artırmak için kullandıkları stratejiler ve (5) öğretmenlerin veli katıllmuyla ilgili eğitim ihtiyaçları. Bulgular, öğretmenlerin veli katılımının önemi ile ilgili farkındalığa sahip olduklarını ancak, veli katılımını artırmak için özel bir girişimde bulunmadıklarını göstermiştir. Ayrıca, öğretmenler çocukların İngilizce gelişimlerinde kendilerini ana figür olarak görürken velileri ise bu süreci destekleyen yardımcı figürler olarak görmektedirler.

Anahtar sözcükler: veli katılımı; öğretmen algıları; çocuklara İngilizce öğretimi; İngilizce öğretmenleri; içerik analizi

\section{AUTHOR BIODATA}

Gülce Kalaycı is a research assistant in Ufuk University English Language Teaching Department. She received her BA and MA degrees in ELT from Hacettepe University.

Hatice Ergül is an Assistant Professor of English Language Teaching at Hacettepe University, Turkey. She has taught a number of courses on language teaching and teacher education over the years. Her research and publication interests include conversation analysis, gender and language, teaching English to young learners, and language teacher education. 